\title{
Hubungan antara kecemasan akademik dan sleep paralysis pada mahasiswa Fakultas Kedokteran Universitas Udayana tahun pertama
}

\author{
Karla Amanda Permata dan Putu Nugrahaeni Widiasavitri \\ Program Studi Sarjana Psikologi, Fakultas Kedokteran, Universitas Udayana \\ putu_nugrahaeni@unud.ac.id
}

\begin{abstract}
Abstrak
Sleep paralysis adalah gangguan tidur dimana individu memiliki kesadaran saat tidur tetapi tidak mampu bergerak dan berbicara dalam beberapa detik atau menit bahkan sulit bernapas serta merasakan sesak di dada. Sleep paralysis dapat dialami paling tidak satu kali dalam hidup manusia. Usia rata-rata individu pertama kali mengalami ganguan tidur ini adalah 14-18 tahun. Salah satu penyebab terjadinya sleep paralysis adalah kecemasan. Sedangkan bentuk kecemasan mahasiswa adalah kecemasan akademik. Kecemasan akademik adalah perasaan gelisah yang tidak menyenangkan yang mempengaruhi kondisi fisik dan psikologis mahasiswa dalam situasi akademik. Penelitian ini bertujuan untuk melihat apakah ada hubungan antara kecemasan akademik terhadap terjadinya sleep paralysis. Subyek dalam penelitian ini adalah 80 mahasiswa Program Studi Pendidikan Dokter Fakultas Kedokteran Universitas Udayana 2016/2017 tahun pertama. Teknik pengambilan sampel yang digunakan adalah sampling daerah. Instrumen penelitian ini adalah skala kecemasan akademik dan skala sleep paralysis. Hasil yang diperoleh dari analisis chi square menunjukkan tidak terdapat hubungan antara kecemasan akademik terhadap terjadinya sleep paralysis.
\end{abstract}

Kata kunci: Sleep paralysis, Kecemasan Akademik, Mahasiswa FK Unud

\begin{abstract}
Sleep paralysis is an occurance of sleep disorder when people have consciousness while sleeping but unable to move or speak for a few seconds up to a few minutes. Some people may also feel pressure or a sense of choking. People usually experience their first sleep paralysis around the age of 14-18 years old. One of the caused of sleep paralysis is anxiety. Anxiety is a common problem on college campuses, one of them is academic anxiety. Academic anxiety is feeling of worrying that affect to physic and psychology in academic situation. This study aimed to identify the relationship between academic anxiety and the incidence of Sleep Paralysis. This Research was using sample amounted 80 students come from Faculty of Medical University of Udayana 2016/2017. Researcher used cluster sampling. The instruments of this research are academic anxiety scale and sleep paralysis scale The result of chi square analysis showed that there's no bound relationship between academic anxiety and the incidence of sleep paralysis.
\end{abstract}

Key words: Sleep paralysis, Academic Anxiety, Faculty of Medicine Udayana Univeristy 


\section{LATAR BELAKANG}

Selama rentan kehidupan manusia mengalami proses pertumbuhan dan perkembangan. Salah satu tahap perkembangan yang dilalui adalah tahap remaja akhir. Mahasiswa semester awal merupakan golongan yang berada pada tahap remaja akhir. Umumnya mahasiswa merupakan individu yang bersekolah di perguruan tinggi dan memiliki tugas untuk berusaha dalam studinya (Bertens, 2005).

Pada semester awal diasumsikan bahwa mahasiswa sedang mengalami perubahan lingkungan dari masa SMA ke jenjang kuliah sehingga harus beradaptasi terhadap lingkungan baru (Chandratika \& Purnawati, 2014). Hal ini dikarenakan adanya perubahan sistem belajar dari siswa ke mahasiswa, suasana dan teman baru, bahkan perbedaan bahasa yang digunakan khususnya pada mahasiswa yang merantau. Hal ini diperkuat oleh Lubis dan Nurlaila (dalam Wulandari, 2012) yang mengatakan bahwa dalam menyelesaikan akademiknya, mahasiswa dihadapkan pada kondisi ujian, adaptasi terhadap perubahan kehidupan perkuliahan, kondisi perbedaan bahasa yang digunakan.

Perubahan yang dialami mahasiswa semester awal terkadang berdampak pada perubahan pola tidur mereka (Puspita, 2015). Maslow (2003) mengatakan bahwa tidur adalah salah satu kebutuhan fisiologis mendasar untuk menyeimbangkan fisiologis dan psikologis manusia. Menurut Guyton (2008) tidur adalah keadaan hilangnya kesadaran seseorang namun dapat dibangunkan kembali menggunakan indera atau rangsangan yang cukup. Tidur juga berfungsi untuk mengurangi stres, kecemasan serta dapat meningkatkan kemampuan dan konsentrasi dalam melakukan aktivitas sehari-hari (Potter \& Perry, 2005). Individu yang memiliki pola tidur yang buruk akan merasa lelah dan mengakibatkan penurunan konsentrasi, karena proses pemulihan yang tidak optimal menyebabkan organ tubuh tidak bisa bekerja. Kuantitas dan kualitas tidur yang buruk akan menyebabkan gangguan tidur.

Menurut American Psychiatric Association, gangguan tidur adalah gangguan utama pola tidur normal yang menyebabkan distress dan mengacaukan fungsi tubuh pada siang hari. Gangguan tidur dapat dialami oleh semua lapisan masyarakat. Termasuk mahasiswa kedokteran yang merupakan kelompok yang rentan mengalami gangguan tidur (Gunanthi dan Diniari, 2015). Hal ini dapat disebabkan karena durasi dan intensitas pendidikan yang tinggi, tugas serta tanggung jawab yang berat. Hasil studi yang dilakukan oleh Kushida, Simon, Grauke, Hyde \& Dement (2000) terhadap 1254 responden yang mengalami gangguan tidur menyatakan bahwa terdapat tiga jenis gangguan tidur yang paling sering terjadi yaitu insomnia, sindrom henti napas saat tidur, dan sindrom kegelisahan saat tidur. Jenis gangguan tidur yang biasa terjadi menurut Perry dan Potter (2005) adalah insomnia, hipersomnia, parasomnia, apnea dan sleep paralysis.

Salah satu gangguan tidur yang ingin dibahas pada penelitian ini adalah gangguan tidur Sleep Paralysis. Sleep paralysis menurut Cheyne (2005) merupakan suatu keadaan saat individu tidur nyenyak, kemudian terbangun secara tiba-tiba dan tidak bisa menggerakkan anggota tubuh. Usia rata-rata orang pertama kali mengalami gangguan tidur ini adalah 1418 tahun. Sleep paralysis bisa terjadi pada laki-laki atau perempuan. Hampir setiap orang pernah mengalaminya setidaknya sekali atau dua kali dalam hidupnya. Sesuai pernyataan Cheyne (1999) yang mengatakan bahwa 30\% sampel yang dilakukan pernah mengalami setidaknya satu kali kejadian Sleep paralysis selama hidupnya. Sleep paralysis berlangsung dalam hitungan detik hingga menit.

Berdasarkan gelombang otak, tidur terbagi dalam 4 tahapan. Tahapan tidur menurut Perry dan Potter (2005) adalah Non Rapid Eye Movement 1 (tahap tidur paling ringan), Non Rapid Eye Movement 2 (tahap tidur yang lebih dalam), Non Rapid Eye Movement 3 (tahap tidur paling dalam), dan Rapid Eye Movement (pada tahap inilah mimpi terjadi). Sleep paralysis terjadi saat seseorang tiba-tiba tersadar sebelum siklus REM berakhir sehingga mengalami kesulitan bergerak dan berbicara (Cheyne, 2002). Sleep Paralysis dapat disebabkan oleh buruknya kualitas dan kuantitas tidur. Tarwoto (2006) menguatkan pendapat bahwa faktor-faktor yang dapat memengaruhi kualitas dan kuantitas tidur antara lain penyakit, lingkungan, kelelahan, gaya hidup, tingkat kecemasan, motivasi, dan obat-obatan.

Salah satu penyebab utama terjadinya sleep paralysis pada mahasiswa kedokteran adalah kurang tidur (Culebras, 2007). Mahasiswa kedokteran seringkali belajar hingga larut malam dengan jadwal tidur yang berubah-ubah. Mayoral (2006) mengatakan bahwa stres dan kecemasan lekat dengan jam tidur rendah.

Saat menyelesaikan studinya, mahasiswa memiliki tuntutan akademik dan non akademik yang dapat menjadi sumber kecemasan. Kecemasan pada bidang akademik seperti kesulitan dalam memahami suatu mata kuliah, tekanan mahasiswa dalam menghadapi ujian dan praktik. Kecemasan non akademik seperti hubungan dengan teman, dosen, finansial, hubungan dengan keluarga, dan lainnya. Menurut Otten (1991) kecemasan akademik adalah masalah penting yang akan memengaruhi sejumlah besar mahasiswa. Kecemasan yang berlebihan akan berpengaruh secara negatif karena mahasiswa mengalami tekanan psikologi, penurunan perhatian dan konsentrasi sehingga mendapatkan hasil belajar yang kurang baik. Seperti yang dikatakan Cornell (2007) kecemasan akademik adalah hasil dari proses biokimia dalam tubuh dan otak yang membutuhkan perhatian, seperti menyelesaikan tugas atau menghadapi ujian. Semua hal yang berhubungan dengan situasi pendidikan di peruguruan tinggi dapat menimbulkan kecemasan akademik (Maddox, 2011). Khan et al. (2012) mengatakan bahwa prevalensi kecemasan lebih tinggi pada mahasiswa tahun pertama dan kedua dibandingkan tahun berikutnya. Masa studi satu tahun pertama merupakan masa penyesuaian dari sekolah menengah yang tidak terlalu berat menuju lingkungan pendidikan yang abru yaitu perguruan tinggi khususnya pendidikan dokter yang berat, penuh tantangan dan lebih kompetitif. 
Di Bali khususnya, di Fakultas Kedokteran Universitas Udayana belum ada penelitian tentang gangguan tidur sleep paralysis pada mahasiswa terutama di awal perkuliahan. Fakultas Kedokteran Universitas Udayana memiliki lima Program Studi antara lain Program Studi Pendidikan Dokter, Program Studi Pendidikan Dokter Gigi, Program Studi Ilmu Keperawatan, Program Studi Fisioterapi dan Program Studi Psikologi. Hasil wawancara pada mahasiswa semester awal fakultas kedokteran mengatakan bahwa sebelum memasuki jadwal kuliah, mahasiswa Fakultas Kedokteran Udayana harus mengikuti orientasi studi dan pengenalan kampus selama empat hari yaitu student day selama dua hari dan PKKMB (Perkenalan Kehidupan Kampus Mahasiswa Baru) selama dua hari. Kegiatan tersebut menuntut mahasiswa kedokteran menyelesaikan tugas yang diberikan oleh senior. Mahasiswa Fakultas kedokteran mengaku tugas yang diberikan sulit untuk diselesaikan karena belum pernah dipelajari saat SMA. Tugas harus diselesaikan dalam waktu yang singkat sehingga mahasiswa tidak memiliki waktu tidur yang cukup. Kuantitas tidur yang buruk memicu terjadinya gangguan tidur.

Mahasiswa Fakultas Kedokteran Universitas Udayana juga mengikuti jadwal kuliah yang padat yaitu SGD (Small Group Discussion), lecture, individual learning, pleno dan praktikum. Penelitian ini fokus pada mahasiswa Fakultas Kedokteran tahun pertama yang sedang mengalami masa transisi perkuliahan. Peneliti telah melakukan wawancara pada 3 mahasiswa kedokteran Universitas Udayana. Hasil wawancara mengatakan bahwa mereka pernah mengalami gangguan tidur sleep paralysis dimalam hari. Mahasiswa Fakultas

Kedokteran Udayana mengaku bahwa mereka mengalami sleep paralysis saat mengikuti kegiatan ospek dan mata kuliah yang padat. Mereka juga mengatakan bahwa terkadang mereka mendengar suara asing, melihat sosok orang lain dan bayangan hitam disekitar tempat tidur. Fenomena ini pun sering dikaitkan dengan hal mistis. Padahal sosok bayangan tersebut adalah halusinasi dari mimpi yang terjadi saat tahap REM (Cheyne, 2002). Akan tetapi halusinasi yang diterima individu akan berbeda dengan individu lain terkait budaya dan lingkungan.

Selain jadwal kuliah, mahasiswa Fakultas Kedokteran Udayana juga dituntut untuk mengikuti salah satu organisasi yang ada di Fakultas Kedokteran Universitas Udayana. Organisasi tersebut juga memberikan tugas dan jadwal organisasi. Mahasiswa mengaku sulit untuk mengatur waktu karena adanya berbagai tugas dari mata kuliah hingga tugas organisasi kampus. Sesuai dengan hasil penelitian Misra dan McKean (2000) bahwa mahasiswa yang lebih muda tingkatannya memiliki kecemasan lebih tinggi dan manajemen waktu yang lebih rendah. Kecemasan akademik juga muncul karena kurikulum yang terlalu tinggi, iklim pembelajaran yang tidak kondusif, pemberian tugas yang padat, sistem penilaian yang ketat, sikap dan perlakuan dosen yang kurang kompeten, serta penerapan disiplin yang ketat (Astuti \& Resminingsih, 2010). Walaupun kecemasan akademik bermanfaat bagi mahasiswa seperti memberikan motivasi untuk giat belajar sebelum ujian (Shahrouri, 2016).
Bentuk kecemasan akademik mahasiswa dapat dilihat dari perilaku mahasiswa saat berada di lingkungan pendidikan. Mahasiswa akan menunjukkan perilaku seperti mudah khawatir, sulit berkonsentrasi dikelas, adanya perubahan fisik seperti otot tegang dan perilaku yang tidak tepat seperti tidak teliti dalam menyelesaikan tugas (Otten, 1991). Mahasiswa kedokteran rentan mengalami kecemasan akademik terutama pada tahun pertama (Armyanti, et al., 2011). Diperkuat oleh hasil penelitian pada mahasiswa kedokteran di United States and

Canadian tahun 2008 menunjukkan bahwa $65.5 \%$ mahasiswa mengalami kecemasan akademik. Ketika cemas biasanya individu tidak fokus dan sulit tidur dimalam hari sehingga tubuh terlalu lelah dan kurang tidur. Saat kecemasan muncul biasanya mahasiswa tidak fokus dan sulit tidur dimalam hari sehinga tubuh terlalu lelah dan kurang tidur. Gelombang otak tidak mengikuti tahapan tidur yang seharusnya sehingga dapat menimbulkan keadaan sleep paralysis. Meskipun sleep paralysis ini biasa terjadi dan dialami oleh mahasiswa, tetapi gangguan tidur ini patut diwaspadai. Pasalnya, sleep paralysis bisa juga merupakan pertanda narcolepsy (serangan tidur mendadak tanpa tandatanda mengantuk), sleep apnea (mendengkur), kecemasan, atau depresi (Larasaty, 2012).

Berdasarkan paparan diatas, maka perlu dilakukan penelitian mengenai hubungan antara kecemasan akademik dan sleep paralysis pada mahasiswa tahun pertama. Melalui penelitian ini diharapkan mahasiswa mengetahui penyebab kecemasan akademik yang berdampak terjadinya sleep paralysis.

\section{METODE PENELITIAN}

Penelitian ini menggunakan metode penelitian kuantitatif non parametrik dikarenakan penelitian ini tidak memenuhi syarat.

\section{Variabel dan Definisi Operasional}

Variabel bebas dari penelitian ini adalah kecemasan akademik dan variabel tergantung dari penelitian ini adalah sleep paralysis. Definisi operasional dari variabel-variabel dalam penelitian ini adalah sebagai berikut:

$\underline{\text { Kecemasan Akademik }}$

Kecemasan akademik adalah perasaan tegang dan ketakutan pada sesuatu yang akan terjadi, perasaan tersebut mengganggu dalam pelaksaan tugas dan aktivitas yang beragam dalam situasi akademik (Valiante \& Pajares, 1999). Kecemasan akademik adalah masalah yang penting yang mempengaruhi sejumlah besar mahasiswa. Ketika kecemasan berlebihan akan berpengaruh secara negatif karena mahasiswa mengalami tekanan psikologis sehingga berdampak pada hasil belajar yang kurang baik dan cenderung menghindari tugas, hal ini disebabkan karena penurunan perhatian, penurunan konsentrasi dan memori pada mahasiswa. Ottens (1991) membagi karakteristik kecemasan akademik menjadi 4, yaitu: Patterns of Anxiety-Engedering Mental Activity (Pola kecemasan yang menimbulkan aktivitas mental), Misderected Attention (perhatian yang menunjukkan arah yang salah), 
Physiological Distress (distres secara fisik) dan Innappropriate Behaviors (perilaku yang kurang tepat).

Sleep paralysis

Sleep paralysis terjadi ketika seseorang berada pada tidur paling dalam saat seluruh otot relaksasi (The American Sleep Disorder Association, 1994). Selama sleep paralysis tubuh tidak dapat bergerak, sementara otak tetap memproduksi mimpi- mimpi. Sleep paralysis memengaruhi sebagian besar tubuh kecuali pada mata. Meskipun seseorang tidak dapat menggerakan tubuh, tetapi mereka masih dapat membuka mata mereka dan melihat lingkungan mereka. Cheyne (2005) mengatakan ada dua aspek sleep paralysis yaitu ciri fisik dan jenis halusinasi. Ciri fisik seperti tidak mampu bergerak ketika sedang tidur ataupun ketika bangun tidur, tidak mampu berbicara, dada terasa sesak atau merasa tercekik. Sedangkan jenis halusinasi seperti halusinasi visual dan halusinasi auditori.

\section{Responden}

Populasi pada penelitian ini adalah Mahasiswa Fakultas Kedokteran Universitas Udayana tahun pertama angkatan 2016/2017. Subjek dalam penelitian ini memiliki karakteristik sebagai berikut: (a) Subjek merupakan remaja akhir yang berusia 18 sampai 20 tahun, (b) Subjek sedang menempuh pendidikan di Program Studi Pendidikan Dokter Fakultas Kedokteran Universitas Udayana.angkatan 2016/2017 kelas A.

Teknik pengambilan sampel yang dilakukan dalam penelitian ini adalah dengan menggunakan salah satu probability sampling yaitu two stage cluster sampling. Two stage cluster sampling adalah teknik mengambil sampel dengan dua tahap pengambilan sampling dari kelompok. Tahap pertama menentukan sampel daerah dan tahap berikutnya menentukan orang-orang yang ada pada daerah tersebut dengan menggunakan sampling juga (Sugiyono,

2015).

\section{Tempat Penelitian}

Lokasi penelitian adalah ruang kuliah Mahasiswa Program Studi Pendidikan Dokter kelas A angkatan 2016/2017. Penelitian ini dilaksakan tanggal 15 Maret 2017.

\section{Alat Ukur}

Alat ukur yang digunakan dalam penelitian ini adalah skala kecemasan akademik dan skala sleep paralysis. Skala kecemasan akademik dalam penelitian ini merupakan skala likert yang menggunakan empat pilihan jawaban, yaitu sangat sesuai (SS), sesuai (S), tidak sesuai (TS), dan sangat tidak sesuai (STS). Skala kecemasan akademik disusun berdasarkan aspek- aspek kecemasan akademik menurut Ottens (1991) meliputi Patterns of Anxiety-Engedering Mental Activity (Pola kecemasan yang menimbulkan aktivitas mental), Misderected Attention (perhatian yang menunjukkan arah yang salah), Physiological Distress (distres secara fisik) dan Innappropriate Behaviors (perilaku yang kurang tepat).

Skala sleep paralysis dalam penelitian ini merupakan skala Guttman dalam bentuk checklist yang menggunakan dua pilihan jawaban. Pilihan "ya" skor 1 dan "tidak" skor 0. Pengukuran skala sleep paralysis diambil dari penelitian sebelumnya mengacu teori Cheyne (2005) meliputi aspek ciri fisik dan jenis halusinasi. Hasil ukurnya adalah responden dinyatakan "pernah" mengalami sleep paralysis apabila jawaban "ya" $\geq 1$ dan dinyatakan "tidak pernah" mengalami apabila tidak ada satu jawaban "ya".

Penyebaran skala uji coba alat ukur dilaksanakan pada Hari Rabu, 08 Maret 2017 dengan melibatkan Mahasiswa Program Studi Pendidikan Dokter kelas B angkatan 2016/2017 di ruang kuliah mahasiswa. Jumlah sampel yang digunakan pada tahap uji coba item adalah 60 orang. Menurut Azwar (2015) secara tradisional, statistika menganggap jumlah sampel yang lebih dari 60 orang sudah cukup banyak.

Melalui uji coba alat ukur didapatkan hasil bahwa uji coba skala kecemasan akademik yang terdiri dari 54 item menghasilkan 25 item valid dan 29 item gugur. Item-item yang valid memiliki koefisien korelasi item-total berkisar antara 0,316 sampai 0,608. Hasil uji reliabilitas skala kecemasan akademik dengan menggunakan teknik Alpha Cronbach menunjukkan koefisien Alpha $(\alpha)$ adalah 0,862. Uji coba skala sleep paralysis menghasilkan 8 item valid. Itemitem yang valid memiliki nilai koefisien korelasi item-total berkisar antara 0,494 sampai 0.776 . Hasil uji reliabilitas skala sleep paralysis dengan menggunakan teknik Alpha Cronbach menunjukkan koefisien Alpha $(\alpha)$ adalah 0,887.

\section{Prosedur Pengambilan Data}

Penelitian ini menggunakan metode penelitian kuantitatif dengan menggunakan salah satu probability sampling yaitu two stage cluster sampling. Two stage cluster sampling adalah teknik mengambil sampel dengan dua tahap pengambilan sampling dari kelompok. Tahap pertama menentukan sampel daerah dengan populasi Mahasiswa Fakultas Kedokteran Universitas Udayana tahun pertama angkatan 2016/2017 yang terdiri dari lima prodi. Tahap berikutnya menentukan orang-orang yang ada pada daerah tersebut dengan menggunakan sampling juga (Sugiyono, 2015).

\section{Teknik Analisis Data}

Data penelitian dianalisis menggunakan uji statistik nonparametrik. Uji statistik non- parametrik yang digunakan adalah uji chi square. Uji statistik non-parametrik digunakan karena tidak memenuhi syarat uji statistik parametrik, salah satunya adalah data yang berdistribusi tidak normal. Uji analisis chi square dilakukan pada dua variabel, dimana skala data kedua variabel adalah nominal. Skala nominal memberikan seberapa banyak atau seberapa sering sesuatu itu muncul. Untuk mencari hasil uji chi square menggunakan analisis crosstab. Uji hipotesis menggunakan program bantu SPSS 17.

\section{Isu Etik Penelitian}

Penelitian yang tepat diharapkan memerhatikan isu etika dalam setiap proses pengambilan data. Kehormatan, kenyamanan dan keamanan data subjek penelitian harus menjadi prioritas utama saat peneliti mengambil data. Tertulis pada lembar persetujuan untuk berpartisipasi yakni informed consent. 


\section{HASIL PENELITIAN}

\section{Karakteristik Subjek}

Berdasarkan data karakteristik subjek, diperoleh bahwa total subjek berjumlah 90 mahasiswa dengan jenis kelamin perempuan sebanyak 50 dan jenis kelamin laki-laki sebanyak 30 mahasiswa. Mayoritas subjek berusia 18 tahun yaitu 50 mahasiswa.

\section{Deskripsi Data Penelitian}

Hasil deskripsi statistik pada tabel 1 (Terlampir) menunjukkan bahwa kecemasan akademik memiliki mean teoritis sebesar 62.5 dan mean empiris sebesar 54.71. Berdasarkan penyebaran frekuensi menghasilkan rentang skor subjek penelitian berkisar antara 42 sampai 83. Sedangan sleep paralysis memiliki mean teoritis sebesar 4 dan mean empiris sebesar 2.84 dan penyebaran frekuensi menghasilkan rentang skor subjek penelitian berkisar antara 0 sampai 8 .

Peneliti melakukan pengkategorisasian skor kecemasan akademik subjek. Skor kecemasan akademik dibagi menjadi tiga yakni kategori rendah, sedang dan tinggi. Sedangkan kategori sleep paralysis dibagi menjadi dua yaitu ya dan tidak.

Dari hasil kategorisasi kecemasan akademik pada tabel 2 (terlampir) menunjukkan bahwa subjek dengan taraf kecemasan akademik sedang berjumlah 59 orang $(73.75 \%)$

$\mathrm{n}$ adalah adalah subjek yang pernah mengalami sleep paralysiss $25 \%$ ) dan sebanyak 27 mahasiswa tidak pernah mengalami sleep paralysis $(33.75 \%)$. (tabel 3. terlampir).

\section{Uji Hipotesis}

Uji hipotesis dalam penelitian ini menggunakan uji chi square. Uji chi square dilakukan untuk melihat apakah terdapat hubungan antara kecemasan akademik dan sleep paralysis pada Mahasiswa Program Studi Pendidikan Dokter Fakultas Kedokteran Universitas Udayana.

Hasil uji chi square pada tabel 4 (terlampir) menunjukkan bahwa pada bagian pearson chi square sebesar 0.524 dan nilai Asymp.Sig sebesar 0.770. Nilai Asymp.Sig sebesar 0.770>0.05, maka dapat disimpulkan bahwa Ha ditolak dan $\mathrm{H} 0$ diterima, yang artinya dapat disimpulkan bahwa tidak ada hubungan yang signifikan antara kecemasan akademik terhadap sleep paralysis pada mahasiswa Fakultas Kedokteran Universitas Udayana.

\section{PEMBAHASAN DAN KESIMPULAN}

\section{Pembahasan}

Berdasarkan hasil penelitian yang telah dipaparkan, subjek penelitian ini adalah mahasiswa Program Studi Pendidikan Dokter 2016/2017 tahun pertama. Presentase subjek berusia 18 tahun sebanyak (63\%), 19 tahun sebanyak (31\%) dan 20 tahun (6\%). Mayoritas subjek dalam penelitian ini adalah perempuan (62.5\%) sedangkan laki-laki $(37.5 \%)$.

Kecemasan akademik mayoritas berada pada kategori kecemasan sedang yaitu 59 orang $(73.75 \%)$ Sanitiara et al.
(2014), kecemasan akademik berada paling banyak pada kriteria sedang 73 orang (72.3\%). Setara dengan hasil penelitian Febri (2016) mengatakan bahwa sebanyak 63\% mahasiswa berada dikategori sedang.

Djumadi (2015) mengatakan bahwa di Indonesia dilaporkan sebanyak 25\% mahasiswa mengalami kecemasan rendah, $60 \%$ cemas sedang, dan $15 \%$ mengalami kecemasan tinggi. Subjek terdiri dari 39 mahasiswa perempuan mengalami kecemasan akademik sedang (48.75\%) sedangkan laki-laki sebanyak 20 mengalami kecemasan akademik sedang (25\%). Menurut National Comorbidity Survey prevalensi kecemasan pada laki-laki $2 \%$ dan perempuan $4,3 \%$. Neelam (2013) juga mengatakan bahwa mahasiswa perempuan lebih mudah mengalami kecemasan akademik dibandingkan mahasiswa laki-laki.

Pada deskripsi statistik data penelitian menunjukkan bahwa kecemasan akademik memiliki mean teoritis sebesar 62.5 dan mean empiris sebesar 54.71 yang berarti saat dilakukan penelitian rata-rata subjek berada pada kategori kecemasan akademik sedang, artinya mahasiswa kurang menunjukkan adanya dorongan pikiran dan perasaan akan ketakutan dalam menghadapi tugas dan aktivitas akademis sehingga pola pikir, respon fisik dan perilaku pun tidak terganggu (Pratiwi, 2009).

Mahasiswa dihadapkan oleh banyak pekerjaan, tantangan dan tuntutan antara lain tugas, laporan, ujian dan kompetisi antar mahasiswa. Hal ini lah yang berpotensi menimbulkan adanya kecemasan akademik. Winkel (1997) mengatakan kecemasan akademik terjadi karena informasi tidak tersimpan dalam bentuk sistematika yang baik, informasi sulit ditemukan dan penggalian tidak berhasil. Kecemasan akademik mengacu pada pola pemikiran dan respon fisik serta perilaku karena kemungkinan performa yang ditunjukkan oleh mahasiswa tidak begitu baik (Sanitiara, et al.,2014). Meskipun mahasiswa dihadapkan pada kurikulum dan tuntutan yang tinggi, faktanya kecemasan akademik mahasiswa dalam penelitian ini berada pada kategori sedang.

Menurut Gail (2002) kecemasan akademik sedang memungkinkan individu untuk berfokus pada hal-hal yang dianggapnya penting dan mengesampingkan yang lain. Hal ini berarti bahwa seseorang yang memiliki kecemasan akademik sedang, masih mampu menggunakan akal sehatnya untuk memilih hal yang baik dan hal yang buruk. Berbeda dengan mahasiswa yang memiliki kecemasan akademik tinggi, biasanya memiliki motivasi yang kurang dikelas sehingga sulit berkonsentrasi (Hancock, 2001). Donelly (2009) mengatakan bahwa kecemasan akademik mahasiswa bermanfaat untuk memberikan dorongan motivasi dan tanggungjawab serta membantu mahasiswa memiliki kehidupan yang lebih dewasa. Tanpa kecemasan akademik, mahasiswa tidak memiliki motivasi untuk menjadi lebih baik sehingga kecemasan akademik dalam tingkat sedang membantu mahasiswa belajar untuk ujian dan cenderung menginginkan prestasi yang lebih baik (Banga \& Sharma, 2016).

Ketika mengerjakan tugas dan ujian, seringkali mahasiswa 
Kedokteran Udayana mendapatkan nilai yang tidak sesuai dengan harapannya. Mahasiswa mengetahui dan menerima kemampuan sendiri sehingga kekurangan dan kegagalan yang diterima tidak menjadi penghambat dalam prestasi yang ingin dicapai (Gunarsa, 2001). Mahasiswa mampu menerima hasil sehingga tidak membiarkan hal tersebut menjadi salah satu sumber kecemasan akademik tinggi. Mahasiswa yang memiliki kecemasan akademik rendah dan sedang memiliki manfaat sebagai pembangkit dalam membantu mahasiswa dalam kegiatan akademik dan dapat memotivasi mahasiswa lain dalam mengerjakan tugas (Otten, 1991). Seperti halnya mahasiswa Program Studi Pendidikan Dokter Fakultas Kedokteran Udayana yang seringkali mengerjakan tugas secara berkelompok (small group discussion), dengan adanya SGD tersebut mahasiswa kedokteran dapat berdiskusi dan berpendapat sehingga mahasiswa lain termotivasi menjadi mahasiswa yang lebih baik agar tidak tertinggal dalam suatu pelajaran. Hal ini sesuai dengan Fiyanti (2003) yang menyatakan bahwa beberapa dari mahasiswa berpikir cara untuk menghilangkan kecemasan yang mereka rasakan adalah dengan cara bersaing. Bersaing yang dimaksud dalam hal ini adalah melakukan perbuatan untuk menjadi pribadi unggul di kelas.

Pada kategori sleep paralysis mayoritas pernah mengalami sleep paralysis yaitu sebanyak 53 mahasiswa (66.25\%). Menurut Liu (2007) sebanyak 62\% dari 148 mahasiswa Ottawa Canada dilaporkan mengalami setidaknya satu kali kejadian sleep paralysis selama hidupnya. Tabel 14 menunjukkan sebanyak 23 mahasiswa laki-laki (28.75\%) dan sebanyak 30 mahasiswa perempuan (37.5\%) pernah mengalami sleep paralysis. Sebuah studi menunjukkan kecenderungan gangguan tidur terjadi pada kelompok mahasiswa perempuan baik pada mahasiswa kedokteran maupun mahasiswa bidang lainnya (Gunanthi dan Diniari, 2015). Mahasiswa yang pernah mengalami gangguan tidur sleep paralysis memiliki total skor $\geq 1$.

Perry \& Potter (1997) mengatakan bahwa beberapa faktor yang memengaruhi gangguan tidur antara lain gaya hidup, lingkungan yang tidak nyaman, emosi yang tidak stabil, pola tidur mengantuk pada siang hari, latihan fisik dan kelelahan, asupan makanan dan kalori. Mahasiswa dapat mengalami gangguan tidur karena gaya hidup dalam aktifitas dan kegiatan yang dilakukan sehari-hari. Seperti yang diketahui bahwa mahasiswa kedokteran memiliki jadwal kuliah yang cukup padat serta wajib mengikuti salah satu organisasi di lingkungan Fakultas Kedokteran Udayana. Kegiatan tersebut dapat menyita waktu dan tenaga sehingga dapat menyebabkan fisik menjadi lelah. Ketika mahasiswa merasa lelah sepanjang hari, ia akan merasakan ketidaknyamanan di malam hari (Wulandari, 2012). Hal ini dapat menyebabkan mahasiswa sulit rileks. Namun, tingkat rileks setiap mahasiswa berbedabeda sehingga walaupun ada beberapa mahasiswa yang tidak lelah, ia tetap merasa kesulitan untuk rileks (DeLaune \& Ladner, 2002). Lingkungan yang tidak nyaman juga dapat memengaruhi kondisi tidur seseorang. Faktor utama dalam pengaturan tidur adalah cahaya dan kegelapan. Hermawati (2010) melakukan penelitian dan mendapatkan hasil bahwa cahaya memengaruhi tidur.
Hasil analisis menunjukkan bahwa mahasiswa dengan kecemasan akademik rendah, sedang dan tinggi bisa saja mengalami gangguan tidur sleep paralysis. Sebanyak 53 mahasiswa kedokteran permah mengalami sleep paralysis (66.25\%) sedangkan sisanya 27 mahasiswa kedokteran tidak pernah mengalami sleep paralysis (33.75\%). Kejadian sleep paralysis dilaporkan meningkat pada mahasiswa dimana $24-42 \%$ pernah mengalami setidaknya satu episode saat berada di bangku kuliah (Awadalla et al., 2004). Menurut The American Sleep Disorder Association (1994) sleep paralysis adalah salah satu gangguan tidur

yang terjadi ketika seseorang berada pada tidur paling dalam saat seluruh otot relaksasi dimana tubuh tidak bisa bergerak tetapi otak masih memproduksi mimpi-mimpi yang didukung oleh halusinasi. Sleep paralysis terjadi ketika seseorang tiba-tiba tersadar sebelum siklus REM berakhir (Cheyne, 2002). Hasil uji chi square menunjukkan nilai sebesar 0.77 dimana nilai tersebut lebih besar daripada 0.05 . Hal tersebut menunjukkan bahwa tidak ada hubungan yang signifikan antara kecemasan akademik dan sleep paralysis pada Mahasiswa Program Studi Pendidikan Dokter Universitas Udayana tahun pertama. Berdasarkan paparan hasil penelitian pada analisis data dan hasil penelitian didapatkan bahwa pengujian hipotesis dalam penelitian ini adalah $\mathrm{H} 0$ diterima.

Sleep paralysis ternyata tidak dipengaruhi oleh tingkat kecemasan akademik mahasiswa, melainkan dipengaruhi oleh beberapa faktor lain. Culebras (2007) mengatakan bahwa penyebab terjadinya sleep paralysis antara lain kurang tidur, kondisi mental seperti cemas dan stres, tidur terlentang, masalah tidur lain seperti narkolepsi, dan penyalahgunaan zat kimia. Mahasiswa kedokteran cenderung terlambat memulai tidur tetapi diharuskan bangun lebih awal untuk memulai aktifitas pembelajaran (Gunanthi dan Diniari, 2015), maka kurang tidur adalah faktor utama mahasiswa kedokteran mengalami sleep paralysis.

Faktor lain yang menyebabkan terjadinya sleep paralysis adalah kondisi mental seperti cemas dan stres. Larasati (2012) mengatakan bahwa hasil penelitiannya menunjukkan terdapat hubungan antara tingkat stres dan kejadian sleep paralysis. Sesuai dengan penelitian Mellman, et al. (2008) yang mengatakan bahwa sleep paralysis berhubungan dengan tingkat stres.

Posisi tidur mahasiswa juga berpengaruh pada kejadian sleep paralysis. Posisi terlentang adalah posisi tidur yang beresiko empat kali lebih sering mengalami sleep paralysis. Sesuai dengan penelitian yang dilakukan oleh Spanos (1995) menemukan sebanyak $70 \%$ subjek mengalami sleep paralysis saat tidur dengan posisi terlentang.

Faktor penyebab terjadinya sleep paralysis lainnya adalah gangguan tidur seperti narkolepsi. Yoss \& Daly (1957) mengatakan bahwa sleep paralysis dipengaruhi oleh narkolepsi. Narkolepsi adalah rasa kantuk yang tak tertahankan saat siang hari yang disebabkan oleh kerusakan genetik sistem saraf pusat sehingga tidak terkendalinya 
periode tidur REM. Didukung oleh hasil penelitian Sturzenegger \& Bassetti (2004) terdapat 49\% subjek dengan riwayat narkolepsi mengalami sleep paralysis.

Peneliti memiliki beberapa kelemahan dalam melakukan penelitian ini. Peneliti melakukan wawancara saat mahasiswa memasuki semester satu, dimana mahasiswa sedang mengalami masa transisi perkuliahan. Pada mahasiswa semester satu diasumsikan bahwa mahasiswa sedang mengalami perubahan lingkungan dari masa SMA ke jenjang kuliah sehingga harus beradaptasi terhadap lingkungan baru (Chandratika \& Purnawati, 2014). Hal ini dikarenakan adanya perubahan sistem belajar dari siswa ke mahasiswa. Adaptasi terhadap suasana dan lingkungan baru bahkan perbedaan bahasa yang digunakan khususnya pada mahasiswa yang merantau.

Peneliti melakukan pengambilan data disaat mahasiswa sudah memasuki semester dua. Mahasiswa semester dua sudah memiliki penyesuaian diri yang baik. Scheneiders (1964) mengatakan bahwa individu yang memiliki penyesuaian diri yang baik adalah individu dengan segala keterbatasan dan kemampuannya telah belajar untuk bereaksi terhadap diri sendiri dan lingkungannya dengan efisien, matang, bermanfaat, dan memuaskan.

Setelah melakukan prosedur analisis data penelitian, karya tulis ini telah mencapai tujuan penelitian yaitu mengetahui apakah ada hubungan kecemasan akademik terhadap sleep paralysis pada mahasiswa Program Studi Pendidikan Dokter Fakultas Kedokteran Universitas Udayana tahun pertama.

\section{Kesimpulan}

Berdasarkan hasil analisis data penelitian dan pembahasan, maka dapat disimpulkan bahwa tidak terdapat hubungan antara kecemasan akademik dan sleep paralysis pada mahasiswa Program Studi Pendidikan Dokter Fakultas Kedokteran Universitas Udayana. Mahasiswa Program Studi Pendidikan Dokter Fakultas Kedokteran angkatan 2016 mayoritas mengalami kecemasan akademik sedang $(73.75 \%)$ dan mayoritas mahasiswa Program Studi Pendidikan Dokter Fakultas Kedokteran tahun pertama 2016/2017 pernah mengalami sleep paralysis $(66.25 \%)$.

\section{Saran}

Saran yang dapat diberikan adalah bagi mahasiswa diharapkan mampu menyadari adanya kecemasan akademik tinggi. Bila kecemasan akademik dirasa menganggu, yang dapat dilakukan adalah bercerita kepada orang terdekat seperti orang tua, teman atau guru untuk dapat membantu menyelesaikan masalah yang menjadi kecemasan akademik. Mahasiswa juga diharapkan mampu menyadari adanya gangguan tidur sleep paralysis yang dapat mengganggu pola tidur sehingga jika mahasiswa sering mengalami sleep paralysis, mahasiswa mampu mengurangi angka kejadian tersebut dengan cara meningkatkan kualitas dan kuantitas tidur.

Saran bagi peneliti selanjutnya adalah menggunakan sampel yang lebih besar serta metode lain agar data yang diperoleh lebih representative dan bervariasi. Peneliti selanjutnya juga diharapkan dapat mengambil data kecemasan akademik disaat mahasiswa masih berada di semester awal dimana diasumsikan masih mengalami transisi dari masa SMA. Peneliti selanjutnya diharapkan mampu membuat skala sleep paralysis dengan skala likert. Pada penelitian ini belum diperoleh data frekuensi terjadinya sleep paralysis pada mahasiswa sehingga peneliti selanjutnya diharapkan mampu mendapatkan angka rata-rata sleep paralysis.

\section{DAFTAR PUSTAKA}

Abrahams, M dan Mulligan, A. (2007). Prevalence and Correlates of Sleep Paralysis in Adults

Reporting Childhood Sexual Abuse. Journal of Anxiety Disorders, 22.

Alam, M. J. F. (2017). Impact and Factors of Academic Anxiety: A Review. IJARIIE International Journal, 3.

Alloy, dkk. (2005). Abnormal Psychology : Current Perspective Ninth Edition. New York : Mc.Graw Hill.

Alsa, Asmadi. (2004). Pendekatan Kualitatif dan Kuantitatif serta Kombinasinya dalam penelitian Psikologi. Yogjakarta: Pustaka Pelajar.

American Psychiatric Association, 2000. Diagnostic And Statistical Manual of Mental Disorders (4th Ed., Text Rev.). Washington, DC: Author

Asmadi. (2008). Tehnik prosedural keperawatan: Konsep dan applikasi kebutuhan dasar klien. Jakarta: Salemba Medika.

Astuti dan Resminingsih. (2010). Pelayanan Konseling Pada Satuan Pendidikan Menengah. Jilid 1. Jakarta: Grasindo.

Azwar, S. (2000). Reliabilitas dan Validitas. Yogyakarta: Pustaka Pelajar. (2000). Sikap Manusia : Teori dan Pengukuran. Yogyakarta: Liberty. (2013). Metode Penelitian. Yogyakarta: Pustaka Belajar. (2015). Penyusunan Skala Psikologi Edisi 2. Yogyakarta: Pustaka Belajar.

Banga \& Sharma. (2016). A Study of Academic Anxiety of Secondary School Students of Kangra District In Relation To Gender, Locale and Social Category. International Multidisciplinary E-Journal. Vol-V Issue IV.

Banga, C.L.(2015). A Study of Academic Anxiety among Private Senior Secondary School. Kangra District, IJELLH, V-III, Issue-1. Bertens, K. (2005). Metode Belajar untuk Mahasiswa. Jakarta. PT. Gramedia Pustaka

Boediono \& Koster, W. (2001). Teori dan Aplikasi Statistika dan Probabilitas. Bandung: PT Remaja Rosdakarya.

Brunner and Suddarth. (2002). Buku Ajar Keperawatan Bedah. Edisi 8. Jakarta: EGC

Center for Learning \& teaching. 2005. Understanding Academic anxiety. Cornell University

Chandratika, D., \& Purnawarti, S. (2014). Gangguan Cemas Pada Mahasiswa Semester I dan VII Program Studi Pendidikan Dokter Fakultas Kedokteran Universitas Udayana. e- Jurnal Medika Udayana.

Cheyne, J. A. (2002). Situational factors affecting sleep paralysis and associated hallucinations: position and timing effects. Canadian Journal of Psychiatric.

Cheyne, J. A. (2005). Sleep paralysis episode frequency and number, types, and structure of associated hallucinations. Journal of Sleep Research, 14.

Chopra, D.( 2003). Tidur Nyenyak, Mengapa Tidak? Ucapkan Selamat Tinggal pada Insomnia. Yogyakarta: Ikon Teralitera.

Culebras, A. (2007). Sleep Disorder and Neurologic Disease. New York: Marcel Dekker. Daradjat, Zakiah. 1988. Kesehatan Mental. Jakarta: Gunung Agung. 
Delaune, S, C \& Ladner, P,K. (2002). Fundamentals of Nursing Standart and Practice. New York: Thomson Delmar Learning.

Denis, dkk. (2017). A Systematic Review of Variabeles associated with Sleep Paralysis. Sleep Medicine Journal.

Djumadi, A. (2015). Hubungan Antara Tingkat Kecemasan Dengan Prestasi Akademik Mahasiswa di Fakultas Psikologi Universitas Muhammadiyah Surakarta. Skripsi. Surakarta: Universitas Muhammadiyah Surakarta.

Donnelly, R. (2009). Embedding interaction within a blend of learner centric pedagogy and technology. World Journal on Educational Technology, 1 (1)

Gail, Stuart W. Buku Saku Keperawatan Jiwa. Jakarta: EGC;2002.

Ganda. (2004), Petujuk Praktis Cara Mahasiswa Belajar di Perguruan Tinggi. Jakarta: Grasindo.

Gillian. (2008). Sleep Paralysis and Hallucinations: What clinicians need to know. The Irish Psychologist, Vol.36, No.5

Gunanthi, M dan Diniari (2016). Prevalensi dan Gambaran Gangguan Tidur Berdasarkan Karakteristik Mahasiswa Semester 1 Program Studi Pendidikan Dokter Fakultas Kedokteran Universitas Udayana Tahun 2015. E-Journal Medika, Vol.5, No.4

Gunarsa, Singgih, D. (2003). Psikologi Untuk Keluarga. Jakarta: Gunung Mulia.

Guyton, A.C, dan Hall, J.E. (2008). Buku Ajar Fisiologi Kedokteran Edisi 11. Jakarta: EGC

Hancock, D. R (2001). Effect of test anxiety and evaluative threats on students's achievement and motivation. The Journal of Education Research, 94 (5), 284-290

Hinton, D. (2005). Sleep Paralysis among Cambodian refugees: association with PTSD diagnosis and severity. Pubmed Us National Library of Medicine National Institutes of Health. Vol 2.

Hurlock, 2003. Psikologi Perkembangan. Jakarta: Erlangga

Ishtifa, H. (2011). Pengaruh Self-Efficacy Dan Kecemasan Akademis Terhadap Self-Regulated Mahasiswa Fakultas Psikologi Universitas Islam Negeri Jakarta. Jakarta: Universitas Islam Negeri Syarif Hidayatullah.

Japardi, I. (2002). Gangguan Tidur. Skripsi. Sumatra Utara: Universitas Sumatera Utara

Kay. (2010). 21st Century skills: Why They Matter, What They Are, and How We Get There. Bloomington, IN: Solution Tree.

Keltney L, Schwecke C \& Bostrom C. (1999). Psychiatric nursing. 4th ed. USA: Mosby INC Khan, R., (2012). A Study of Anxiety among Senior Secondary School Students in relation to

Gender, Academic Streams and Types of School. Research Journal, $11(1)$.

Kushida, et all. (2000). Symptom-Based Prevalence of Sleep Disorders in an Adult Primary Care Population. Thesis. California: Standford University.

La Greca, et al. (1998). Social Anxiety Among Adolescents: Linkages with Peer Relations and

Friendships. Journal of Abnormal Child Psychologi, 26.

Larasaty,R. (2012). Hubungan Tingkat Stres dengan Kejadian Sleep Paralysis Pada Mahasiswa FIK UI Angkatan 2008. Skripsi. Depok: Universitas Indonesia. Maslow, Abraham. (2003). Motivasi dan Kepribadian. Jakarta: Midas Surya Grafindo.

Mayoral, L. (2006). Exam stress, depression, social support, and sleep disturbance. Thesis. New York: San Jose State University.

Mellman, dkk. (2008). Sleep Paralysis and Trauma, Psychiatric Symtoms and Disorder in an Adult African American Population Attending Primary Medical Care. Journal of Depress Anxiety, 25.
Neelam. (2013). Academic anxiety and achievement of secondary school students -a study on gender differences, International Journal of Behavioral Social and Movement Sciences, Vol.02,Issue01.

Nevid, J.S, Rathus, S.A \& Green, B. (2003). Psikologi Abnormal Jilid 1. Jakarta: Erlangga

Nugroho,W. (2006). Keperawatan Gerontik \& Geriatrik. Jakarta: EGC

Ohaeri, B. M. (2004). Features of isolated sleep paralysis among Nigerians. East African Medical Journal, 81.

Ottens, Allen J. (1991). Coping With Academy Anxiety (Rivised edition). New York: The Rosen Publishing Group, Inc

Papalia, D.E., Old, S.W., dan Feldman, R.D. (2008). Human Development (Psikologi Perkembangan). Jakarta: Kencana.

Patlak, M. (2005). Yoyr Guide to Healthy Sleep. U.S Department of Health and Human Services. Diakses dari www.nhlbi.nih.gov/helath/public/helathy_sleep.pdf pada tanggal 18 Februari 2017.

Poerwadarminta, W.J.S . (2005). Kamus Umum Bahasa Indonesia. Edisi Ketiga. Jakarta: Balai Pustaka.

Potter, P.A dan Perry, A.G. (2005). Buku Ajar Fundamental Keperawatan: Konsep, Proses, dan Praktik. Jakarta: EGC.

Pratiwi, A. P. (2009). Hubungan Antara Kecemasan Akademis Dengan Self-Regulated

Learning Pada Siswa Rintisan Sekolah Bertaraf Internasional Di SMA Negeri 3 Surakarta. Semarang: Universitas Diponegoro.

Priyatno, Dwi. (2008). Mandiri Belajar SPSS Untuk Analisis Data dan Uji Statistik, Mediakom.

Puspita, O. (2015). Perubahan Pola Hidup Sehari-Hari Mahasiswa Perantau Asal Aceh Jaya Di

Kota Banda Aceh. Tesis. Banda Aceh: Universitas Syiah Kuala.

Rafknowledge. (2004). Insomnia dan Gangguan Tidur Lainnya. Jakarta: Elex Media Komputindo.

Rola, F dan Nasution, L. (2010). Hubungan Antara Kecemasan Akademik Dengan Academic Self Management Pada Siswa SMA Kelas X Unggulan. Skripsi. Sumatera: Universitas Sumatera Utara.

Sanitiara, et al. (2014). Hubungan Kecemasan Akademis Dengan Regulasi Diri Dalam Belajar

Pada Mahasiswa Tahun Pertama Fakultas Kedokteran Universitas Riau Tahun 2013/2014. Jurnal Online Mahasiswa UNRI. Vol.4, No.2

Santrock, John W. (2007). Perkembangan Anak. Jilid Edisi Kesebelas. Jakarta: PT. Erlangga.

Setyohutomo, I. (2014). Hubungan Kecemasan Akademis Dengan Perilaku Menyontek di SMA Negeri 7 Surakarta. Surakarta: Universitas Muhammadiyah Surakarta.

Simard, V \& Nielsen, T.A. (2005). Sleep paralysis-associated sensed presence as a possible manifestation of social anxiety. American Psychological Association Net, 15.

Stuart, G. W \& Laraian, M.T. (2005). Principles and practice of pyshiatric nursing 8th edition. Missouri: Mosby. INC

Submanova \& Elizaveta. (2007). Sensed Presence As A Correlate of Sleep Paralysis Distress, Social Anxiety and Waking State Social Imagery. Journal of National Institutes of Health, 1.

Sugiyono. (2010). Metode Penelitian Kuanititatif Kualitatof \& RND. Bandung: Alfabeta

Suryabrata,S. (2000). Metodologi Penelitian. Jakarta: PT Raja Grafindo Persada.

Suryani, A.O. (2007). Gambaran Sikap Terhadap Hidup Menjelang dan Kecemasan akan Ketidakhadiran Pasangan Pada Wanita Lajang Berusia di Atas 30 Tahun. Jurnal Ilmiah Psikologi Manusia.1 (1), 75-93

Tarwoto \& Wartonah. (2006). Kebutuhan Dasar Manusia dan Proses Keperawatan, Edisi 3. Jakarta: Salemba Medika 
Tarwoto \& Wartonah. (2006). Kebutuhan Dasar Manusia Dan Proses Keperawatan. Edisi ke-3. Jakarta: Salemba Medika.

The American Sleep Disorders Association Accreditation Committee. (1994). Standards for accreditation of sleep disorders centers. Rochester, Minnesota: American Sleep Disorders Association.

Utama, C (2015). Gambaran Kecemasan Akademik Mahasiswa Kuliah di dua Fakultas di

Medan. Tesis. Sumatera: Universitas Sumatera Utara.

Valiante, G., \& Pajares, F. (1999). The inviting/disinviting index: Instrument validation and relation to motivation and achievement. Journal of Invitational Theory and Practice, 6.

Winkel, W.S. (1997). Bimbingan dan Konseling di Institusi Pendidikan. Jakarta: PT. Grasindo

Wong, D, dkk. 2009. Buku ajar Keperawatan Pediatrik. Volume 1. Penerbit Buku Kedokteran EGC: Jakarta

Woyo, Dwi. (2007). Ilmu Pendidikan. Yogyakarta: UNY Press.

Wulandari, R. (2012). Hubungan Tingkat Stres dengan Gangguan Tidur Pada Mahasiswa Skripsi Di Salah Satu Fakultas Rumpun Science-Technology UI. Depok: Universitas Indonesia

Yusuf, Muri. (2012). Metode Penelitian Kuantitatif, Kualitatif \& Penelitian Gabungan. Edisi

Pertama. Jakarta: PT Fajar Interpertama Mandiri

Yusuf, Syamsu. (2012). Psikologi Perkembangan Anak dan Remaja. Bandung: Remaja Rosdakarya. 


\section{LAMPIRAN}

Tabel 1

\begin{tabular}{cccccccccc}
\hline Variabel & $\mathrm{N}$ & $\begin{array}{c}\text { Mean } \\
\text { Teoritis }\end{array}$ & $\begin{array}{c}\text { Mean } \\
\text { Empiris }\end{array}$ & $\begin{array}{c}\text { Std } \\
\text { Deviasi } \\
\text { Teoritis }\end{array}$ & $\begin{array}{c}\text { Std } \\
\text { Deviasi } \\
\text { Empiris }\end{array}$ & $\begin{array}{c}\text { Sebaran } \\
\text { Teoritis }\end{array}$ & $\begin{array}{c}\text { Sebaran } \\
\text { Empiris }\end{array}$ & $\mathrm{T}$ \\
\hline KA & 80 & 62.5 & 54.71 & 12.5 & 6.422 & $25-100$ & $42-83$ & $\begin{array}{c}-10.846 \\
\mathrm{p}=(0,000)\end{array}$ \\
\hline SP & 80 & 4 & 2.84 & 1.33 & 2.384 & $0-8$ & $0-8$ & $\begin{array}{c}-4.362 \\
\mathrm{p}=(0,000)\end{array}$ \\
\hline
\end{tabular}

Deskripsi Statistik Data Penelitian

Tabel 2

Kategorisasi Kecemasan Akademik

\begin{tabular}{cccc}
\cline { 3 - 4 } Rentang Nilai & Kategori & Jumlah & Persentase \\
\hline $\mathrm{X} \leq 50$ & Rendah & 20 & 25 \\
\hline $50<\mathrm{X} \leq 75$ & Sedang & 59 & $73.75 \%$ \\
\hline $75 \leq \mathrm{X}$ & Tinggi & 1 & $1.25 \%$ \\
\hline
\end{tabular}

Tabel 3

Kategori Sleep Paralysis

\begin{tabular}{|c|c|c|}
\hline Sleep Paralysis & Jumlah & Persentase \\
\hline $\mathrm{Ya}_{\mathrm{a}}$ & 53 & $66.25 \%$ \\
\hline Tidak & 27 & $33.75 \%$ \\
\hline Total & 80 & $100 \%$ \\
\hline
\end{tabular}

